\title{
Game analysis of stakeholders' actions affecting the development of green buildings
}

\author{
Shuyuan Zhao $^{1}$ and Yihui Huang ${ }^{1, a}$ \\ ${ }^{1}$ College of Civil Engineering,HuaQiao University,Xiamen 361021,China
}

\begin{abstract}
As the government pays more attention to the ecological environment, the momentum of green buildings in China has developed rapidly in recent years. However, the continuous and good development of green buildings is also related to the attitude of developers and consumers. This paper analyzes the game from the perspectives of the government, developers and consumers, and provides feasible suggestions for the development of green buildings in China.
\end{abstract}

\section{Introduction}

In recent years, the momentum of green buildings(GBs) in China has developed rapidly. A series of laws and regulations have been successively promulgated to promote the development of green buildings. For example, in 2006, China issued the " Assessment standard for green building" (GB/T50378-2006), and in 2015, implemented the new version of the "New Assessment standard for green building" ${ }^{[1]}$ (GB/T50378-2014), and also implemented the "Green Buildings Evaluation Marking System" in 2008.

\subsection{The Obstacles of Green Buildings}

Besides the government supports the implementation of green buildings, the attitudes of other stakeholders also influence the development of green buildings ${ }^{[2]}$. Albert P. C. Chan ${ }^{[3]}$ thought that Resistance of stakeholders to change and higher cost are identified as the most critical barriers to implementing GB technologies. Wang Min $^{[4]}$ and others believed that China's construction market participants at present are less willing to actively participate in the development of green buildings.

\subsection{The Game Theory of Green Buildings}

Now, stakeholders of researches for green buildings mainly include government, developers, owners (consumers) and other related parties. Huang Dingxuan ${ }^{[5]}$ conducted a research on the basis of profit-risk evolutionary game theory of developers and owners (consumers), and found that projects size, incremental costs, pure benefits and risk for green building projects will affect the game behaviors of developers and owners. Liu $\mathrm{Jia}^{[6]}$ pointed out that under the government's increasing economic incentives for green buildings and raising the taxation standards for non-green buildings, these measures will promote the game between the government and the developers, so as to promote the development of green buildings.

Therefore, this paper proposes to establish a static game model of incomplete information for the government, developers, and owners (consumers) that influence the implementation of green buildings, and integrates the benefits, costs, risks, and coping strategies of the three parties into a unified game model.

\section{Stakeholders Affecting Development of Green Buildings}

the

\subsection{Government}

Under the current conditions of China, the government's incentive strategies for the large-scale development of green buildings are mainly carried out in the following three ways: (1) government subsidies: because of the high incremental costs of green buildings to developers in the early stage, the government reduces developers' costs and mobilizes the enthusiasm of developers through subsidies (2) taxation policies: government reduces taxation of green buildings developers and raises taxation of traditional buildings developers (3) sponsor of green technologies development: the government needs supporting research and development units to conduct research on green buildings' technical standards, materials, evaluations, and energy efficiency.

\subsection{Developers}

Some large real estate developers have formulated green buildings development strategies, continuously improved the green level and quality of buildings and obtained green buildings logos. Although the number and area of

* Corresponding author: ${ }^{a}$ huangyihui@hqu.edu.cn 
green projects have also rapidly increased, due to high incremental costs, some developers still hesitate to build green buildings. Most companies understand that the implementation of green buildings can achieve financial incentives, increase sales expectations, and gain good social influence. However, there are still large uncertainties and risks in the development of green buildings.

\subsection{Consumers}

Consumers choose to buy green buildings or not. When consumers purchase green buildings, they can enjoy the health and environmental protection functions of green buildings. However, due to the current imperfect green buildings market, consumers are still skeptical about the purchase of green buildings. This will affect the relationship between supply and demand of green buildings, affecting developers' willingness of development.

\section{Three-Party Game Model Affecting the Development of Green Buildings}

\subsection{Assumptions and Construction of the Three-party Game Model}

Assume that the government, the developer, and the consumer are all "rational economic people" (remarked as $\mathrm{G}, \mathrm{D}, \mathrm{C})$. The government's strategic space is: incentive, denoted as $\mathrm{G}+$; no incentive, as $\mathrm{G}-$; developer's strategic space: development, recorded as D+; no development, as D-; consumer's strategic space is: purchase, marked as $\mathrm{C}+$; no purchase, as $\mathrm{C}^{-}{ }^{[7]}$. Based on the above assumptions of the model, the strategy combinations of the three parties in the game model are $(\mathrm{G}+, \mathrm{D}+, \mathrm{C}+),(\mathrm{G}+, \mathrm{D}+, \mathrm{C}-),(\mathrm{G}+, \mathrm{D}-, \mathrm{C}+),(\mathrm{G}+, \mathrm{D}-, \mathrm{C}-)$, (G-, D+, C+), (G-, D+, C-), (G-, D-, C+), (G-, D-, C-). Assume that the probabilities of government incentive, developer development, and consumer purchase are respectively $\alpha, \beta$, and $\gamma(\alpha, \beta, \gamma \in[0,1])$.

\subsection{Three-Party Game Parameters and Revenue Matrix}

(1) the parameters in this paper are shown :

Table 1. Parameters

\begin{tabular}{|c|c|c|}
\hline Parties & Parameters & The meaning \\
\hline \multirow{7}{*}{ G } & $\mathrm{R}_{11}$ & Basic income when the government does not take incentives \\
\hline & $\mathrm{R}_{12}$ & Social reputation and influence gained from the supports to development of GBs \\
\hline & $\mathrm{R}_{13}$ & Increases taxation to Non-GBs Developers \\
\hline & $\mathrm{C}_{11}$ & Subsidies for GBs developers \\
\hline & $\mathrm{C}_{12}$ & Subsidies for GBs consumers \\
\hline & $\mathrm{C}_{13}$ & Governance costs for traditional buildings developed by developers \\
\hline & $\mathrm{C}_{14}$ & Government Fund R\&D Units for Research on GBs Technology \\
\hline \multirow{7}{*}{$\mathrm{D}$} & $\mathrm{R}_{21}$ & Corporate credibility increased by the development of GBs \\
\hline & $\mathrm{R}_{22}$ & The incentive subsidies from government obtained by the development of GBs \\
\hline & $\mathrm{R}_{23}$ & Increased revenue from the development of energy, water, electricity saving for GBs \\
\hline & $\mathrm{R}_{24}$ & The benefit from the development of Non-GBs \\
\hline & $\mathrm{C}_{21}$ & the increased risk of no purchase of consumers when the developers develop GBs \\
\hline & $\mathrm{C}_{22}$ & Incremental costs for green operations \\
\hline & $\mathrm{C}_{23}$ & Incremental tax costs when developing traditional buildings \\
\hline \multirow{5}{*}{$\mathrm{C}$} & $\mathrm{R}_{31}$ & The basic utility enjoyed by consumers when purchasing traditional buildings \\
\hline & $\mathrm{R}_{32}$ & Better living, product and environment for consumers to buy GBs \\
\hline & $\mathrm{R}_{33}$ & The incentive subsidies from government obtained by the purchase of GBs \\
\hline & $\mathrm{C}_{31}$ & The incremental costs when consumers purchase GBs \\
\hline & $\mathrm{C}_{32}$ & The incremental risk faced by consumers in purchasing GBs \\
\hline
\end{tabular}

(2)Game strategies and revenue matrix
Table 2. Revenue Matrix

\begin{tabular}{|c|c|l|l|}
\hline \multirow{2}{*}{ D-er } & \multirow{2}{*}{$\mathrm{C}$} & \multicolumn{2}{|c|}{$\mathrm{G}$} \\
\cline { 3 - 4 } & & \multicolumn{1}{|c|}{$\alpha$} & \multicolumn{1}{|c|}{ No I $1-\alpha$} \\
\hline & & & \\
$\mathrm{D}$ & $\mathrm{P}$ & $\mathrm{R}_{11}+\mathrm{R}_{12}-\mathrm{C}_{11}-\mathrm{C}_{12}-\mathrm{C}_{14}$ & $\mathrm{R}_{11}$ \\
$\beta$ & $\gamma$ & $\mathrm{R}_{21}+\mathrm{R}_{22}+\mathrm{R}_{23}+\mathrm{R}_{24}-\mathrm{C}_{22}$ & $\mathrm{R}_{21}+\mathrm{R}_{23}+\mathrm{R}_{24}-\mathrm{C}_{22}$ \\
& & $\mathrm{R}_{31}+\mathrm{R}_{32}+\mathrm{R}_{33}-\mathrm{C}_{31}-\mathrm{C}_{32}$ & $\mathrm{R}_{31}+\mathrm{R}_{32}-\mathrm{C}_{31}-\mathrm{C}_{32}$ \\
\hline
\end{tabular}




\begin{tabular}{|c|c|c|c|}
\hline & $\begin{array}{l}\text { No P } \\
1-\gamma\end{array}$ & $\begin{array}{l}\mathrm{R}_{11}+\mathrm{R}_{12}-\mathrm{C}_{11}-\mathrm{C}_{14} \\
\mathrm{R}_{21}+\mathrm{R}_{22}+\mathrm{R}_{23}+\mathrm{R}_{24-}-\mathrm{C}_{21}-\mathrm{C}_{22} \\
\mathrm{R}_{31}\end{array}$ & $\begin{array}{l}\mathrm{R}_{11} \\
\mathrm{R}_{21}+\mathrm{R}_{23}+\mathrm{R}_{24}-\mathrm{C}_{21}-\mathrm{C}_{22} \\
\mathrm{R}_{31}\end{array}$ \\
\hline \multirow{2}{*}{$\begin{array}{l}\text { No } \\
\text { D } \\
1-\beta\end{array}$} & $\begin{array}{l}\mathrm{P} \\
\gamma\end{array}$ & $\begin{array}{l}\mathrm{R}_{11}+\mathrm{R}_{12}+\mathrm{R}_{13}-\mathrm{C}_{13}-\mathrm{C}_{14} \\
\mathrm{R}_{24}-\mathrm{C}_{23} \\
\mathrm{R}_{31}\end{array}$ & $\begin{array}{l}\mathrm{R}_{11-}-\mathrm{C}_{13} \\
\mathrm{R}_{24}-\mathrm{C}_{23} \\
\mathrm{R}_{31}\end{array}$ \\
\hline & $\begin{array}{l}\text { No P } \\
1-\gamma\end{array}$ & $\begin{array}{l}\mathrm{R}_{11}+\mathrm{R}_{12}+\mathrm{R}_{13}-\mathrm{C}_{13}-\mathrm{C}_{14} \\
\mathrm{R}_{24-}-\mathrm{C}_{23} \\
\mathrm{R}_{31}\end{array}$ & $\begin{array}{l}\mathrm{R}_{11-}-\mathrm{C}_{13} \\
\mathrm{R}_{24-}-\mathrm{C}_{23} \\
\mathrm{R}_{31}\end{array}$ \\
\hline
\end{tabular}

(G means government, D-er means developers, C means consumers, I means incentive, D means development, $\mathrm{P}$ means purchase)

\subsection{Model Establishment and Results Analysis}

(1) Let $E_{1}$ and $E_{2}$ represent the expected revenue of government when it motivates and not-motivates to green buildings' development, respectively. Based on the three-party game model,

$$
\begin{aligned}
\mathrm{E}_{1}= & \beta\left[\gamma\left(\mathrm{R}_{11}+\mathrm{R}_{12}-\mathrm{C}_{11}-\mathrm{C}_{12}-\mathrm{C}_{14}\right)\right. \\
& \left.+(1-\gamma)\left(\mathrm{R}_{11}+\mathrm{R}_{12}-\mathrm{C}_{11}-\mathrm{C}_{14}\right)\right] \\
& +(1-\beta)\left[\gamma\left(\mathrm{R}_{11}+\mathrm{R}_{12}+\mathrm{R}_{13}-\mathrm{C}_{13}-\mathrm{C}_{14}\right)\right. \\
& \left.+(1-\gamma)\left(\mathrm{R}_{11}+\mathrm{R}_{12}+\mathrm{R}_{13}-\mathrm{C}_{13}-\mathrm{C}_{14}\right)\right] \\
= & \left(\mathrm{R}_{11}+\mathrm{R}_{12}+\mathrm{R}_{13}-\mathrm{C}_{13}-\mathrm{C}_{14}\right)-\beta\left(\gamma \mathrm{C}_{12}+\mathrm{C}_{11}+\mathrm{R}_{13}-\mathrm{C}_{13}\right) \\
\mathrm{E}_{2}= & \beta \mathrm{R}_{11}+(1-\beta)\left(\mathrm{R}_{11}-\mathrm{C}_{13}\right)=\mathrm{R}_{11}+(\beta-1) \mathrm{C}_{13}
\end{aligned}
$$

From the above, we can see that the government's revenue is:

$$
\begin{aligned}
& \mathrm{E}_{\mathrm{G}}=\alpha \mathrm{E}_{1}+(1-\alpha) \mathrm{E}_{2} \\
& =\alpha\left(\mathrm{R}_{12}+\mathrm{R}_{13}-\mathrm{C}_{14}\right)-\alpha \beta\left(\gamma \mathrm{C}_{12}+\mathrm{C}_{11}+\mathrm{R}_{13}\right) \\
& \quad+\beta \mathrm{C}_{13}+\mathrm{R}_{11}-\mathrm{C}_{13} \\
& \left\{\begin{array}{l}
\frac{\partial E_{G}}{\partial \alpha}=\left(R_{12}+R_{13}-C_{14}\right)-\beta\left(\gamma C_{12}+C_{11}+R_{13}\right) \\
\frac{\partial E_{G}}{\partial \beta}=C_{13}-\alpha\left(\gamma C_{12}+C_{11}+R_{13}\right) \\
\frac{\partial E_{G}}{\partial \gamma}=-\alpha \beta C_{12}<0
\end{array}\right.
\end{aligned}
$$

Because of the government's subsidies to consumers, it can be seen that the greater the consumer's purchase possibility, the smaller the government's revenues. However, the government can increase its revenue through its own motivation for the development of green buildings and the response of developers. Analyze as below:

When

$$
\begin{gathered}
\beta \leq \frac{R_{12}+R_{13}-C_{14}}{\mathcal{C}_{12}+C_{11}+R_{13}} \\
\left(\beta>\frac{R_{12}+R_{13}-C_{14}}{\chi_{12}+C_{11}+R_{13}}\right),
\end{gathered}
$$

the revenue of the government increases(decreases) with the increase of the developer's probability of developing green buildings;

When

$$
\begin{gathered}
\alpha \leq \frac{{ }_{12}+C_{11}+R_{13}}{C_{13}} \\
\left(\alpha>\frac{\chi_{12}+C_{11}+R_{13}}{C_{13}}\right),
\end{gathered}
$$

the revenue of the government increases (decreases) with its own possibility of supporting green buildings.

(2) Let the expected revenue of the developer's development and non-development of green buildings be $E_{3}$ and $E_{4}$, respectively. According to the three-party game model,

$$
\begin{aligned}
& \mathrm{E}_{3}= \alpha\left[\gamma\left(\mathrm{R}_{21}+\mathrm{R}_{22}+\mathrm{R}_{23}+\mathrm{R}_{24}-\mathrm{C}_{22}\right)\right. \\
&\left.+(1-\gamma)\left(\mathrm{R}_{21}+\mathrm{R}_{22}+\mathrm{R}_{23}+\mathrm{R}_{24}-\mathrm{C}_{21}-\mathrm{C}_{22}\right)\right] \\
&+(1-\alpha)\left[\gamma\left(\mathrm{R}_{21}+\mathrm{R}_{23}+\mathrm{R}_{24}-\mathrm{C}_{22}\right)\right. \\
&\left.+(1-\gamma)\left(\mathrm{R}_{21}+\mathrm{R}_{23}+\mathrm{R}_{24}-\mathrm{C}_{21}-\mathrm{C}_{22}\right)\right] \\
&= \alpha \mathrm{R}_{22}+\gamma \mathrm{C}_{21}+\mathrm{R}_{21}+\mathrm{R}_{23}+\mathrm{R}_{24}-\mathrm{C}_{21}-\mathrm{C}_{22} \\
& E_{4}=R_{24}-C_{23}
\end{aligned}
$$

So, the developers'revenue is:

$$
\begin{aligned}
& \mathrm{E}_{\mathrm{D}}=\beta \mathrm{E}_{3}+(1-\beta) \mathrm{E}_{4} \\
& \quad=\alpha \beta \mathrm{R}_{22}+\beta \gamma \mathrm{C}_{21}+\beta\left(\mathrm{R}_{21}+\mathrm{R}_{23}-\mathrm{C}_{21}-\mathrm{C}_{22}+\mathrm{C}_{23}\right) \\
& \left\{\begin{array}{l}
\frac{\partial E_{D}}{\partial \alpha}=\beta R_{22}>0 \\
\frac{\partial E_{D}}{\partial \beta}=\alpha R_{22}+\gamma C_{21}+R_{21}+R_{23}-C_{22}-C_{21}+C_{23} \\
\frac{\partial E_{D}}{\partial \gamma}=\beta C_{21}>0
\end{array}\right.
\end{aligned}
$$

It can be seen that the higher the possibility of government motivation, the greater the expected revenue of developers; the higher the likelihood of consumers purchase, the greater the expected revenue of developers. However, the developer's degree of development has the following effects on its revenue:

When

$$
\alpha \geq \frac{R_{21}+R_{23}-C_{22}-C_{21}+C_{23}-C_{21}}{R_{22}},
$$

the developer's revenue increases with the developers' development level;

When

$$
\alpha<\frac{R_{21}+R_{23}-C_{22}-C_{21}+C_{23}-C_{21}}{R_{22}},
$$

the developer's revenue decreases with the developers' development level.

When

$$
\gamma \geq \frac{R_{21}+R_{23}-C_{22}-C_{21}+C_{23}-\alpha R_{22}}{C_{21}},
$$

the developers' revenue increases with the developers' development level;

When

$$
\gamma<\frac{R_{21}+R_{23}-C_{22}-C_{21}+C_{23}-\alpha R_{22}}{C_{21}},
$$

the developer's revenue decreases with the developers' development level.

(3)Let $E_{5}$ and $E_{6}$ represent the expected revenue for 
consumers purchase and non-purchase for green buildings, respectively. Based on the three-party game model,

$$
\begin{gathered}
\mathrm{E}_{5}=\alpha\left[\beta\left(\mathrm{R}_{31}+\mathrm{R}_{32}+\mathrm{R}_{33}-\mathrm{C}_{31}-\mathrm{C}_{32}\right)+(1-\beta) \mathrm{R}_{31}\right] \\
+(1-\alpha)\left[\beta\left(\mathrm{R}_{31}+\mathrm{R}_{32}-\mathrm{C}_{31}-\mathrm{C}_{32}\right)+(1-\beta) \mathrm{R}_{31}\right] \\
=\alpha \beta \mathrm{R}_{33}+\beta\left(\mathrm{R}_{32}-\mathrm{C}_{31}-\mathrm{C}_{32}\right)+\mathrm{R}_{31} \\
E_{6}=R_{31}
\end{gathered}
$$

So, the consumers' revenue is:

$$
\begin{aligned}
& \mathrm{E}_{\mathrm{C}}=\gamma \mathrm{E}_{5}+(1-\gamma) \mathrm{E}_{6}=\alpha \beta \gamma \mathrm{R}_{33}+\beta \gamma\left(\mathrm{R}_{32}-\mathrm{C}_{31}-\mathrm{C}_{32}\right)+\mathrm{R}_{31}(1) \\
& \left\{\begin{array}{l}
\frac{\partial E_{C}}{\partial \alpha}=\gamma \beta R_{33}>0 \\
\frac{\partial E_{C}}{\partial \beta}=\alpha \gamma R_{33}+\gamma\left(R_{32}-C_{31}-C_{32}\right) \\
\frac{\partial E_{C}}{\partial \gamma}=\alpha \beta R_{33}+\beta\left(R_{32}-C_{31}-C_{32}\right)
\end{array}\right.
\end{aligned}
$$

The higher level of government incentives, the greater subsidies given to consumers and the revenue of consumers. However, the developer's development possibilities and consumers' own purchasing possibilities have impacts on consumers' expected returns.

When

$$
\begin{gathered}
\alpha \geq \frac{R_{32}-C_{31}-C_{32}}{R_{33}} \\
\left(\alpha<\frac{R_{32}-C_{31}-C_{32}}{R_{33}}\right),
\end{gathered}
$$

the revenue of consumers increases(decreases) with the possibility of developers' development and the possibility of consumers' own purchase.

\section{Conclusions}

In this paper, a mixed game strategy Nash equilibrium is used to analyze the development of green buildings. The conclusion shows that the higher the degree of government motivation, the greater the expected income of developers and consumers, and the more the sustainable development of green buildings. Although the more likelihood of consumers purchase will cause the government's revenue be reduced, the main purpose of the government as the macro-controller is to promote the purchasing power of consumers. In addition, the government can increase its own expectation of revenue in social reputation through this move.

\section{References}

1. M. Wang, S. Chang. Andrew, X. Qin. Vertical and Horizontal Comparative Study of Chinese New Evaluation Standard for Green-building. J. Journal of Engineering Management.30,01,1-6(2016).

2. M. Wimala, E. Akmalah, M R. Sururi. Breaking through the Barriers to Green Building Movement in Indonesia: Insights from Building Occupants. J. Energy Procedia. 100: 469-474(2016).

3. A P C. Chan, A. Darko, E E. Ameyaw, et al. Barriers Affecting the Adoption of Green Building Technologies. J. J. Manage. Eng. 33,3(2017).

4. M. Wang, X. Qin, Y. Mo. Empirical analysis of differences and correlation of challenge factors on green Buildings from stakeholder's perspective. J. China civil engineering Journal. 47, 12: 130-138(2014).

5. D. Huang. Evolutionary game analysis of green building demand side based on profit risk. J. China civil engineering Journal. 50, 02: 110-118(2017).

6. J. Liu, Y. Liu, Y. Shi. Research on the Incentive and Restraint Mechanism of Large Scale Development of Green Building Based on Evolutionary Game Theory. J. Science and Technology management research. 04: 239-243(2016).

7. Q. He, D. Fan, J. Xie. Research on the management mode reformation and the game's rule of megaprojects. J. Journal of TongJi University(Natural Science). 44, 12: 1956-1961(2016). 